*УДК 657.471:658

Яценко В.Ф., к.е.н., доцент

Херсонський національний технічний університет

\title{
ЕВОЛЮЦІЙНИЙ ПІДХІД ДО КЛАСИФІКАЦІї СИСТЕМ ОБЛІКУ ВИТРАТ
}

У статті розглянуто еволюційний розвиток методів обліку витрат під впливом трансформаційних змін у суспільстві і представлено класифікацію систем обліку витрат на основі виокремлення ознак індустріального та постіндустріального етапів розвитку суспільства.

Ключові слова: витрати, витрати виробництва, калькулювання собівартості продукції, система обліку витрат за замовленнями, система обліку витрат за процесами, система обліку за повними витратами.

\section{Yatsenko V.}

\section{EVOLUTIONARY APPROACH TO THE CLASSIFICATION OF COST ACCOUNTING SYSTEMS}

A classification of cost accounting systems based on evolutionary society development is presented. There are two approaches of cost accounting methods classification based on papers of Ukrainian scientists. The first is the classification by country of origin and using, the second is based on the presenting traditional and non-traditional methods.

The author tried to analyze the positions of scientists on the classification of cost accounting methods through evolutionary transformations of economic and social relations. Obtained results allow to divide the history of the cost accounting system development into two periods. The first relates to the industrial era and the industrial revolution and is characterized by the emergence and development of traditional (classical) accounting systems for production costs and its calculation. The second period involves the transition of society to the next post-industrial stage and the emergence of new management concepts that are oriented towards strategic thinking and consumer satisfaction.

Traditional systems of cost accounting include full costing or absorption costing system which is based on the division of costs on the direct and indirect in relation to the object, and variable and fixed costs in relation to the volume of production. Therefore, there are three alternatives: actual-costs, normal-costs, and standard-costs. Two basic models (job costing and process costing) are used for cost accounting in order to calculate self-cost of the product unit according to the peculiarities of the production process. In case, if none of the basic models does not meet the specifics of the production environment, a hybrid-costing system is used, which is a combination of two basic

\footnotetext{
* Яценко В.Ф.
} 
models.

The study has confirmed that the historical development of cost accounting systems was carried out in accordance with the evolutionary society development. Property relations on means of production and class society determined by two models of economic formation. However, obtained results has proved that there is no significant difference between evolutionary development of the accounting systems in the socialist and capitalist economies. Vice versa, cost accounting systems of the industrial stage of society development apart economy models have two fundamental principles: recording only actual (real) data and production process orientation.

Key words. cost, costing system, process costing, job costing, absorption costing (full costing).

Яценко В.Ф.

\section{ЭВОЛЮЦИОННЫЙ ПОДХОД К КЛАССИФИКАЦИИ СИСТЕМ УЧЕТА ЗАТРАТ}

В статье рассмотрены эволюционное развитие методов учета затрат под влиянием трансформационных изменений в обществе и представлена классификация систем учета затрат на основе выделения признаков индустриального и постиндустриального этапов развития общества.

Ключевые слова: затраты, калькулирование себестоимости продукции, система учета затрат по заказам, система учета затрат по процессам, система учета по полным затратам.

Постановка проблеми у загальному вигляді і її зв'язок 3 важливими науковими та практичними завданнями. Усталені традиції обліку в умовах командно-адміністративної системи управління радянської епохи тривалий час домінували у свідомості науковців та бізнес-практиків в Україні. Відкриття кордонів наприкінці XX століття надихнуло академічну спільноту до вивчення та активного пропагування теорій вчених інших країн, переважно Німеччини та США, але економічні реалії того часу не сприяли впровадженню новітніх концепцій, а вітчизняні методи помилково вважалися застарілими і не прийнятними для ринкової моделі економічної системи.

Дослідження систем обліку витрат з точки зору еволюційного розвитку суспільства, враховуючи особливості історичного шляху становлення вітчизняної економічної системи, має суттєве значення для розвитку теорії та методології обліку, а також для вирішення конкретних завдань у бізнес-середовищі.

Аналіз останніх досліджень, у яких започатковано вирі- 
шення проблеми. Поширеним підходом до класифікації методів обліку витрат є групування за країнами виникнення і застосування. Так, до вітчизняних методів та методів країн ближнього зарубіжжя Т. Сльозко відносить попроцесний (простий, однопередільний), попередільний, позамовний, поконтрактний, попартіонної калькуляції, нормативний, котловий, поопераційної калькуляції. Методами далекого зарубіжжя автор вважає Стандарт-кост, Дректкостинг, Таргет-костинг, Кайзен-костинг, Абзорпшн-костинг, Косткілинг, CVP-аналіз, LCC-аналіз, аналіз (ФBA), метод EVA, ABCметод, та бенчмаркінг [1, с. 17].

В.А. Дерій сучасні методи обліку витрат поділяє на дві групи: 1) традиційні, які використовуються у вітчизняній обліковій практиці протягом десятиліть; 2) запозичені, тобто сформовані та розвинуті в інших країнах світу. До традиційних методів вітчизняної облікової науки науковець відносить позамовний, нормативний, знеособлений (котловий), повиробничий, поопераційний, попередільний, попроцесний, групово-виробничий (попартійний), а також два варіанти обліку (безнапівфабрикатний та напівфабрикатний) [2, С.421].

В.В. Дубовая, проаналізувавши нормативні документи, виявляє схожість методів обліку витрат у вітчизняній і зарубіжній практиці. Вона пропонує для наближення вітчизняної бухгалтерської теорії до зарубіжної визнати два основні підходи до формування витрат з використанням зарубіжних назв - позамовного та попроцесного [3, с. 156]. Поряд із позамовним (Job order cost system) i попроцесним (Process cost system) методами С.О. Левицька і Д.М. Сич використовують термін «змішаний метод» для позначення методу обліку прямих затрат за фактичними даними, а накладних за середнім коефіцієнтом розподілу [4, с. 230].

А.С. Немченко та В.М. Назаркіна класифікують методи обліку витрат на виробництво за наступними ознаками: за способом оцінки витрат (за фактичною собівартістю, за плановою собівартістю, за нормативною собівартістю); по відношенню витрат до технологічного процесу виробництва (попередільний, позамовний, попроцесний); по повноті включення витрат до собівартості (по повній собівартості, за прямими витратами, маржинальної собівартості) $[5$, с.40]. 
Германенко Л. методи обліку витрат групує за наступними класифікаційними ознаками: обсяг витрат, що відносяться на їх носії: метод повного поглинання (absorption-cost system) та метод часткового поглинання (direct-cost system); тимчасова спрямованість обчислення фактичних (минулих, історичних) (actual-cost system) затрат та обчислення стандартних (планових, нормативних) (standart-cost system) затрат; технологія виробництва: попроцесний метод (process-cost system) та позаказний метод (job order-cost system) $[6$, c.136].

Інший підхід до класифікації методів обліку витрат і калькулювання собівартості грунтується на виділенні традиційних і нетрадиційних методів. У групі традиційних методів групою авторів [7] представлені методи зарубіжної практики та аналоги у вітчизняному обліку: метод калькулювання по замовленнях (позамовний) та метод попроцесного калькулювання (попередільний); система стандарт кост (система нормування обліку витрат за повною собівартістю) та система директ-кастинг (система нормування обліку витрат за скороченою собівартістю). До нетрадиційних методів віднесли методи «АВС» $\mathrm{i}$ «Target-costing», які не мають аналогів у вітчизняній бухгалтерській науці.

На думку автора, упорядкування позицій науковців щодо класифікації методів обліку витрат потребує розгляду через призму еволюційних перетворень економічно-суспільних відносин для узагальнення теорії і практики обліку витрат індустріального і постіндустріального періодів.

Цілі статті. Метою статті є побудова класифікації систем обліку витрат на основі дослідження еволюційного розвитку суспільства.

Виклад основного матеріалу дослідження 3 обгрунтуванням отриманих наукових результатів. Ідентифікація вітчизняних методів обліку витрат на виробництво продукції як традиційних, які загальновідомі в наукових колах та у практичній діяльності українських підприємств протягом багатьох десятиліть, можна пояснити відсутністю протягом тривалого часу можливості вивчення досвіду зарубіжних країн. Історія виникнення і розвитку систем обліку витрат знаходиться в центрі уваги вчених з усього світу, в тому числі, і проблема встановлення класифікаційних ознак 
для віднесення систем обліку до традиційних (класичних).

Адум Сміт Овунда (Adum Smith Ovunda), детально проаналізувавши різноманітні джерела, які в багатьох випадках недоступні вітчизняним дослідникам, продемонстрував розвиток обліку витрат і управлінського обліку в світі [8]. Він зазначає, що не зважаючи на існування підтверджень про застосування обліку витрат у стародавні часи та використання деяких рахунків і простих форм обліку витрат у XIV столітті, облік витрат і калькулювання собівартості відносять до XIX століття і пов'язують його з розквітом промислової революції. Проте, Едвардс и Ньюэлл [9, с. 41] заперечують, що калькуляція продукту (product costing) відноситься до XIX століття. Эдвардс [10] як доказ наводить детальний приклад рахунків XVIII століття для калькулювання процесу (process costing) як «потоку виробництва трикотажних виробів» (thread hosiery production).

Основним процесом створення додаткової вартості для промислових підприємств є матеріальне виробництво, проте на початку індустріального етапу розвиту суспільства само підприємство ототожнювалося 3 виробництвом, оскільки сукупні витрати підприємства вважалися виробничими, найбільшу питому вагу 3 яких складали матеріальні витрати. XIX століття характеризується появою крупних підприємств, таких як текстильні фабрики, залізничні дороги, металургійні та інші заводи, які активно використовували машини у виробництві, отже, облік витрат в сучасному розумінні $\epsilon$ продуктом того часу. Система обліку витрат на виробництво мала декілька центрів, в яких збиралися прямі витрати на матеріали $\mathrm{i}$ робочу силу, а непрямі витрати розподілялися між ними на основі заздалегідь визначених ставок. Джонсон і Каплан [11] описали систему обліку витрат на виробництво гігантської сталеливарної компанії, яка безперервно збирала дані про всі прямі витрати, пов'язані 3 кожним процесом виробничої діяльності від доменної печі до прокатного цеху. Також вони зазначають, що основні методи обліку витрат (cost methods), серед яких відзначають попроцесний метод (process costing) та нормативний (standard costing) з'явилися саме в період промислової революції, проте ці методи значно покращилися вже на початку XX століття. Поряд із масовим виробництвом функціонували підприємства, які спеціалізувалися на виконанні індивідуальних замовлень клієнтів і виробництві ексклюзив- 
них видів продукції, для яких системою обліку витрат і калькулювання собівартості стала «позамовна» (англомовний синонім «Јоb costing / Job cost accounting«). Отже, можна стверджувати, що облік витрат за замовленнями та процесами є базовими моделями обліку витрат на виробництво і калькулювання собівартості продукції.

Аналогічна ситуація спостерігається в Україні, де методи обліку витрат на виробництво та калькулювання собівартості виникли і розвивалися в період розквіту епохи індустріалізації (19501970 pр), який співпав з радянськими часами, іншими словами в період панування соціалістичної моделі економічної системи. Проте індустріальний етап цивілізаційного розвитку суспільства має спільні риси обох формацій: соціалістичної і капіталістичної, яка рухалася до ринкової, зокрема, розквіт індустріалізації характеризувався великими промисловими підприємствами, які зосереджувалися на масовому виробництві одного виду продукції з метою отримання максимальної вигоди за рахунок ефекту масштабу. Модель «Витрати-обсяг» є концептуальною основою системи обліку витрат та калькулювання собівартості продукції, адже забезпечує даними вхідні параметри моделі. Модель лежить в основі методики CVP-аналізу (аналіз витрат - обсяг виробництва - прибуток, визначення критичної точки виробництва).

Сукупні витрати підприємства в обліку поділяють на виробництво продукції (product cost) та витрати звітного періоду (period cost). Виробнича собівартість продукції у фінансовому обліку включає всі витрати, понесені під час виробництва (full costing або absorption costing): прямі витрати, які можна безпосередньо віднести на виробництво конкретного виду продукції (матеріальні, на оплату праці, інші), та загальновиробничі (накладні), які відносяться до процесу виробництва та розподіляються на конкретний виготовлений продукт на основі ставки розподілення. У складі загальновиробничих витрат виділяють змінну і постійну частини.

Система обліку витрат на виробництво та калькулювання собівартості продукції за повними витратами має три варіанти: (1) за фактичними витратами (actual-costs) - основана на фактичних (icторичних) даних, фіксує прямі витрати на виробництво (матеріальні й на оплату праці) на об'єкт витрат та накладні виробничі витрати для подальшого розподілення між об'єктами витрат; (2) за пла- 
новими (бюджетними, звичайними) витратами (normal-costs) - використовує фактичні прямі матеріальні витрати і витрати на оплату праці, а накладні виробничі витрати розподіляються між носіями витрат за розрахованою заздалегідь плановою ставкою шляхом множення її на фактичну кількість встановленої бази розподілення; (3) за стандартними (нормативними) витратами (standard-costs) попереднє (до початку виробничого процесу) нормування витрат за статтями калькуляції з метою посилення контролю за раціональним використанням ресурсів з явними ознаками надзору.

Три варіанти системи обліку за повними витратами свідчать про поступову переорієнтацію вектору управління витратами 3 реально спожитих/використаних ресурсів підчас виробництва продукції на майбутні (прогнозні) витрати.

Для обчислення собівартості одиниці продукції відповідно особливостям організації виробничого процесу використовують дві базові моделі обліку витрат на виробництво та калькулювання собівартості продукції: за замовленнями (job costing) або процесами (process costing). Якщо жодна із базових моделей не відповідає особливостям виробничого середовища, використовується гібридна система (hybrid-costing system), яка визначається як комбінація двох базових моделей. Вітчизняна практика використовує множину термінів: змішаний метод, напівфабрикатний, тощо , проте, ці методи є різноваріантними комбінаціями двох базових моделей.

В попередніх роботах автором представленої статті відмічалося, що цивілізаційні процеси у світовій економіці призвели до значних змін у бізнес-середовищі. Глобалізація, дерегулювання ринків, формування міжнародних транспортних систем, підвищення вимог клієнтів і покупців до якості продукції посилили конкуренцію між виробниками. Нововведення неодмінно призвели до переформовування виробничої діяльності, моделі поведінки витрат виробництва, отже й методів обліку витрат [12, с. 111-112]. Пріоритетним для управління став процес реалізації продукції замість виробництва, а на основі концепції стратегічного управління виникли і розвиваються нові системи управління витратами, орієнтовані на довгострокові періоди, фактичні витрати, реально понесені підприємством слугують для формування показників фінансової звітності і оподаткування та аналізу і контролю реалізації стратегії 
підприємства (рис.1).

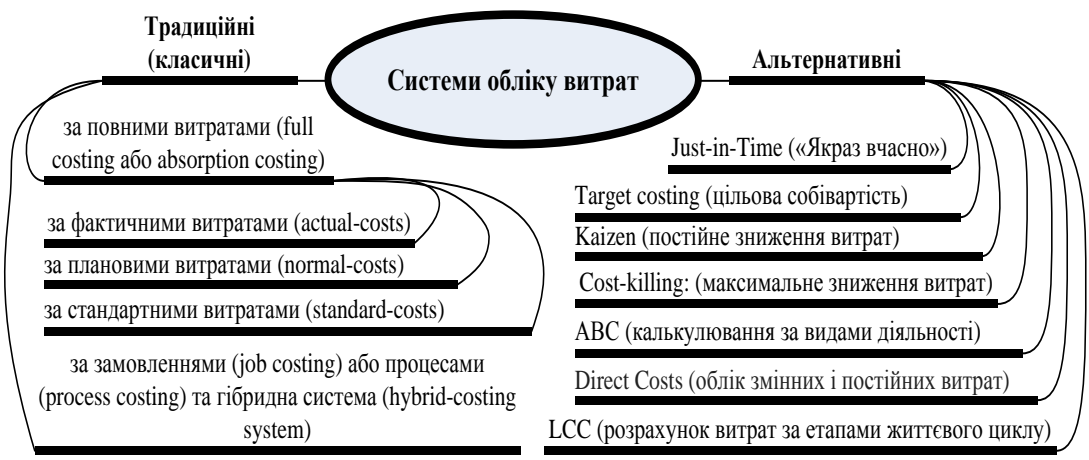

бка)

Рис. 1. Класифікація систем обліку витрат (авторська розро-

Отже, розвиток системи обліку витрат умовно можна поділити на два періоди: (1) відноситься до індустріальної епохи і промислової революції та характеризується виникненням і розвитком традиційних систем обліку витрат на виробництво та калькулювання собівартості продукції; (2) період, пов'язаний 3 переходом суспільства до наступного постіндустріального етапу та виникненням нових концепцій управління, орієнтованих на стратегічне мислення та задоволення вимог споживача.

Висновки. Проведене дослідження підтверджує, що історичний розвиток систем обліку витрат відбувався відповідно до еволюційного розвитку економічно-суспільних відносин у суспільстві. Відносини власності на засоби виробництва та класовий характер суспільства визначали дві моделі економічної формації, проте отримані результати доводять, що еволюційний розвиток систем обліку витрат капіталістичної і соціалістичної моделі економіки суттєвих розбіжностей не мають. Навпаки, системам обліку витрат індустріального етапу розвитку суспільства незалежно від моделі економічної формації притаманні два фундаментальних принципи: фіксування виключно фактичних (реальних) даних та орієнтація на процес виробництва. 
1. Сльозко Т. Методи обліку витрат чи методи управління витратами: проблеми дифініцій //Бухгалтерський облік і аудит. - 2013. - №. 4. - С. 16-21.

2. Дерій В. А. Вітчизняні методи обліку витрат на виробництво: оцінка стану і потенціал застосування //Економічні науки. Серія: Облік і фінанси. - 2010. №. 7 (1). - С. 415-424.

3. Дубовая В. В Концептуальна основа методів обліку витрат у промисловості //Причорноморські економічні студії. - 2016. - №. 12 (2). - С. 154-158.

4. Левицька С. О. Роль управлінського обліку в оптимізації калькулювання собівартості виробництва (на прикладі вітчизняних підприємств малого та середнього бізнесу) / С. О.Левицька , Д. М.Сич //Вісник Національного університету водного господарства та природокористування. Економічні науки. -2015 . - №. 1. - С. 226-234.

5. Немченко, А. С. Обгрунтування методичних підходів до управління собівартістю виробництва лікарських засобів / А. С. Немченко, В. М. Назаркіна // Управління, економіка та забезпечення якості в фармації. - 2015. - № 3. - С. 38 43.

6. Германенко Л. Обгрунтування використання методів обліку витрат та калькулювання в економічних реаліях //Збірник наукових праць Черкаського державного технологічного університету. Серія: Економічні науки. - 2015. - №. 40 (1). - C. 134-140.

7. Чернікова І.Б. Управлінський облік в інформаційній системі підприємства. Навчальний посібник. / І.Б. Чернікова, Л.О.Кирильєва, Д.Д. Шеховцова, О.О.Кваша, І.С.Коробкіна // Харківський державний університет харчування та торгівлі. - Харків: Видавець Іванченко І. С., 2016. - 209 с.

8. Ovunda A. S. The Development of Cost and Management Accounting: A Historical Perspective //European Journal of Humanities and Social Sciences Vol. - 2015. - T. 34. - №. 1.

9. Edwards, J. R. \& Newell, E., (1990). The Development of Industrial Cost and Management Accounting Before 1850: A Survey of Evidence. Business History, 33(1), January.

10. Edwards, R. S., (1937). Some Notes on the Early Literature and Development of Cost Accounting in Great Britain II. The Accountant, Vol. XCVII [New Series], June to December, 14 August.

11. Johson, H. T. \& Kaplan, R. S., (1987 and 1991). Relevance Lost: The Rise and Fall. Journal of Management Accounting Research Vol. 1, Fall.

12. Яценко В.Ф. Облік витрат виробництва: вплив тенденцій постіндустріального етапу розвитку суспільства / В.Ф. Яценко// Науковий вісник Херсонського державного університету. Серія : економічні науки. - Херсон, 2018. - № 30. Частина 4. - С. 109-113. 